\title{
The Role of Physical Activity and Mortality in Hemodialysis Patients: A Review
}

\author{
Fan Zhang ${ }^{1}$, Hui Wang ${ }^{2}$, Weiqiong Wang ${ }^{3}$ and Huachun Zhang ${ }^{4 *}$ \\ ${ }^{1}$ Department of Nephrology, Longhua Hospital Shanghai University of Traditional Chinese Medicine, Shanghai, China, \\ ${ }^{2}$ Department of Anorectal, Longhua Hospital Shanghai University of Traditional Chinese Medicine, Shanghai, China, ${ }^{3}$ Blood \\ Purification Centre, Longhua Hospital Shanghai University of Traditional Chinese Medicine, Shanghai, China, ${ }^{4}$ Department of \\ Nursing, Longhua Hospital Shanghai University of Traditional Chinese Medicine, Shanghai, China
}

Available data indicated that physical activity was related to improved outcomes in hemodialysis patients. Multiple observational studies involving different cohorts have reported that increased physical activity level was associated with decreased mortality among hemodialysis patients. Therefore, promoting physical activity has become an increasingly critical and promising approach to improving cardiovascular health and clinical outcomes in hemodialysis patients. This review summarizes the published articles regarding physical activity and hemodialysis patients, focusing on mortality and strategy to promote physical activity.

Keywords: physical activity, hemodialysis, mortality, strategy, review

\section{INTRODUCTION}

End-stage renal disease (ESRD) is a global health problem characterized by high morbidity and mortality (1). About 600,000+ ESRD patients receive renal replacement therapy, and hemodialysis (HD) accounts for $91.94 \%$ in China (2). In recent years, patients with ESRD have increased life expectancies because of advances in HD (3). Despite this, the risk of premature death in HD patients is 20 times higher than in the general population due to cardiovascular disease in more than $50 \%$ of dialysis patients (4). It causes a burden to the afflicted individuals and their families and the healthcare system (5).

Physical activity refers to any bodily movement produced by skeletal muscles that require energy expenditure (6). Evidence showed that being physically active is vital for maintaining health and preventing the exacerbation of diseases in all populations (7), including patients with ESRD treated by hemodialysis (8). Even light physical activity has been inversely associated with the risk of death among patients with renal disease (9). Importantly, regular physical activity is beneficial across all stages of renal disease, improving physical fitness, muscular strength, and health-related quality of life (10).

Nevertheless, HD patients engage in less physical activity than healthy age-matched controls (11). Meanwhile, inactivity worsens over time and with disease severity (12). Prolonged time spent sedentary was associated with an increased risk of all-cause mortality in HD patients $(13,14)$. Accordingly, there are growing voices to integrate physical activity into routine care among HD patients (15).

This review summarized the available data regarding the associations between physical activity and mortality among HD patients. On the basis, we showed the results of recent randomized controlled trials (RCTs) on modifying physical activity in HD patients and concluded some recommendations for future research. 


\section{PHYSICAL ACTIVITY AND MORTALITY: DATA FROM COHORT STUDIES}

Regular physical activity is associated with a reduced risk of mortality caused by cardiovascular disease, diabetes, obesity, and cancer $(16,17)$. Substantial prospective observational studies of HD patients support the same conclusion (Table 1). In a recent meta-analysis of nine cohort studies, greatest vs. lowest physical activity levels was associated with a $14 \%$ lower risk of all-cause mortality (hazard ratio $(\mathrm{HR})=0.86,95 \%$ confidence interval $(C I), 0.83$ to $0.89 ; P=0.003)$ in patients with endstage renal disease (23). Data from the Dialysis Outcomes and Practice Patterns Study (DOPPS) revealed that mortality risk was lower among patients who engage in regular physical activity (HR $=0.73,95 \% C I, 0.69$ to $0.78 ; P<0.001)$ (24). However, data are limited regarding whether changing physical activity among HD patients is associated with improved mortality. One retrospective analysis in a study of $192 \mathrm{HD}$ patients reported that those who remained stable PA or becoming less active had a 0.93 (95\% CI, 0.75 to $4.99 ; P=0.17)$ and 2.68 (95\% CI, 1.55 to $8.78 ; P<0.01)$ higher risk of all-cause mortality compared to patients becoming more active, independent of the baseline physical activity and patient's characteristics (Figure 1) (25). Taken together, these data support the conclusion that higher levels of physical activity are associated with lower mortality. However, the mechanisms underlying this effect are unknown and still need to be investigated.

\section{STRATEGY TO PROMOTE PHYSICAL ACTIVITY: DATA FROM RANDOMIZED CONTROLLED TRIALS}

Given the insufficient levels of physical activity present among HD patients and the links between sedentary lifestyle and the higher mortality, interventions are needed that can promote HD patient's physical activity. Nine RCTs have evaluated the effects of different strategies on physical activity and have had inconsistent results (Table 2). As a whole, these interventions include (a) pedometer-based intervention based on goal-setting theory; (b) physical activity increase based on exercise interventions to improve physical function; (c) changing the dialysis model.

While some studies have shown positive effects, another portion of the non-statistically significant results warrant further thought: (a) since self-reported physical activity is unreliable,

TABLE 1 | Studies of the association of PA with mortality in HD patients.

\begin{tabular}{|c|c|c|c|c|}
\hline References & Sample & Method & $\begin{array}{l}\text { Follow-up } \\
\text { (years) }\end{array}$ & Finding \\
\hline Hishii et al. (13) & 71 & $\begin{array}{l}\text { Sedentary behavior was measured using } \\
\text { an accelerometer. }\end{array}$ & Mean $3.0 \pm 1.7$ & $\begin{array}{l}\text { HR } 2.83(95 \% \mathrm{Cl}, 1.11 \text { to } 7.32 ; P=0.028) \text { for the } \\
\text { total days, } 2.98(95 \% \mathrm{Cl}, 1.21-8.03, P=0.016) \text { for } \\
\text { the HD days, } 2.79(95 \% \mathrm{Cl}: 1.13-7.49, P=0.024) \\
\text { for the non-HD days. } \\
\text { Reference group: short-sedentary behavior group } \\
\text { (patients with a relative value (\%) of daily wearing } \\
\text { tri-accelerometer time below the median). }\end{array}$ \\
\hline Matsuzawa et al. (18) & 282 & $\begin{array}{l}\text { Physical activity was measured by an } \\
\text { accelerometer. }\end{array}$ & $\begin{array}{l}\text { Median } 4.7 \text { (IQR } \\
2.4-7.0)\end{array}$ & $\begin{array}{l}\text { HR } 2.37 \text { (95\% Cl } 1.22 \text { to } 4.60, P=0.01) \text { for daily } \\
\text { step counts }<4,000 \text {. } \\
\text { Reference group: } \geq 4,000 \text { steps }\end{array}$ \\
\hline Lopes et al. (19) & 5,763 & $\begin{array}{l}\text { Physical activity was measured using the } \\
\text { Rapid Assessment of Physical Activity } \\
\text { (RAPA). }\end{array}$ & $\begin{array}{l}\text { Median } 1.6(\mathrm{IQR} \\
0.9-2.5)\end{array}$ & $\begin{array}{l}\text { HR } 0.89 \text { ( } 95 \% \mathrm{Cl}, 0.72 \text { to } 1.10) \text { for infrequently active, } \\
0.84(95 \% \mathrm{Cl}, 0.67 \text { to } 1.05) \text { for sometimes active, } \\
0.81 \text { ( } 95 \% \mathrm{Cl}, 0.68 \text { to } 0.96 \text { ) for often active, and } 0.60 \\
(95 \% \mathrm{Cl}, 0.47 \text { to } 0.77) \text { for very active group ( } P \text { for } \\
\text { trend < } 0.001) \text {. } \\
\text { Reference group: inactive (each question of RAPA } \\
\text { has a "Yes" or "No" option. The score ranges from } 1 \\
\text { to } 7 \text {; a score of } 6-7 \text { points is considered "very } \\
\text { active," } 4-5 \text { points as "often active," and } \leq 3 \text { points } \\
\text { is defined as "inactive" to "sometime active"). }\end{array}$ \\
\hline Zhang et al. (20) & 317 & $\begin{array}{l}\text { Physical activity was measured by using } \\
\text { the Human Activity } \\
\text { Profile and the Stanford 7-day Physical } \\
\text { Activity Recall Questionnaire (PAR). }\end{array}$ & 3.0 & $\begin{array}{l}\text { Mortality risk decreases by } 0.44 \text { for each point } \\
\text { increase in the maximal activity score, decreasing } \\
\text { by } 0.69 \text { for each increase in light physical activity } \\
\text { time and by } 0.66 \text { for each point increase in the PAR. }\end{array}$ \\
\hline Matsuzawa et al. (21) & 202 & $\begin{array}{l}\text { Physical activity was measured by an } \\
\text { accelerometer. }\end{array}$ & $\begin{array}{l}\text { Mean } 3.75 \text { (range } \\
0.2-7.0 \text { ) }\end{array}$ & $\begin{array}{l}\text { HR } 0.78(95 \% \mathrm{Cl}, 0.66 \text { to } 0.92 ; P=0.002) \text { per } 10 \\
\mathrm{~min} / \text { day increase physical activity. }\end{array}$ \\
\hline O’Hare et al. (22) & 2,264 & $\begin{array}{l}\text { A single question: How often do you } \\
\text { exercise (do physical activity during } \\
\text { your leisure time)? }\end{array}$ & $\begin{array}{l}\text { Median } 1.0 \text { (no } \\
\text { IQR) }\end{array}$ & $\begin{array}{l}\text { HR } 1.62 \text { (95 Cl } 1.16 \text { to } 2.27 \text { ). } \\
\text { Reference group: non-sedentary (responding to the } \\
\text { questionnaire as "almost never or never" was } \\
\text { defined as sedentary). }\end{array}$ \\
\hline
\end{tabular}

$H R$, hazard ratio; IQR, interquartile range; $C I$, confidence interval. 


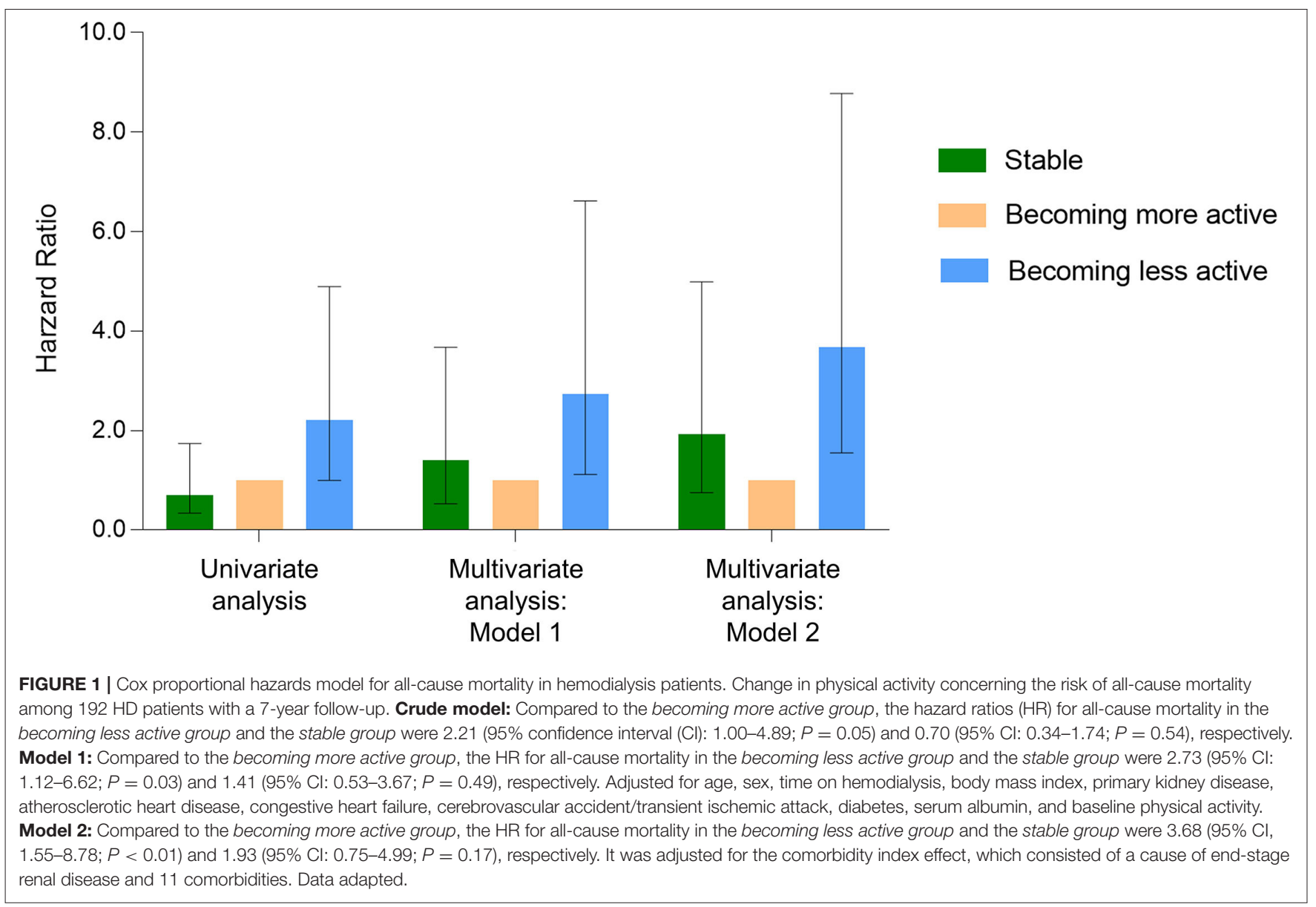

wearable devices, represented by pedometers and accelerometers, were gradually being used for physical activity assessment in $\mathrm{HD}$ patients (35). However, pedometers may be insensitive to detect activity in patients who walk slowly (36). Tri-axis accelerometer, more likely to detect dynamic changes in physical activity (37); (b) the choice of physical activity outcome assessment may determine the success or failure of different measures in promoting physical activity effects. Most RCTs have focused on the impact of interventions on daily step count. It has been suggested that increases in daily steps are not necessarily accompanied by increases in metabolic equivalents or time spent in moderate to vigorous-intensity physical activity (38); (c) given that minor changes in physical activity can elicit health benefits, it may be necessary to transition our thinking from "promoting physical activity" to "active living" (39). This concept includes leisure and domestic activities and transportation (walking and bicycling), although these activities are not necessarily detected by the available measurement tools.

\section{FUTURE DIRECTIONS}

HD patients were generally inactive, and this sedentary nature was detrimental to both quality and quantity of life. Therefore, increased efforts to understand better the determinants of physical activity and practical strategies to improve this variable should be a principal goal in promoting a physically active lifestyle among HD patients. Future research should focus first on the best tools for measuring physical activity for HD patients in clinical practice. The ability to accurately measure physical activity is not optimal in HD patients that are commonly slowmoving (40). The best available device is an accelerometer, yet few have been robustly validated for use in the public. Concerning the few validated accelerometers, undercounting has been shown compared to pedometers (41). There is a significant need to establish a proper and affordable way to objectively measure physical activity in slower-moving populations, particularly for lighter activity levels. This likely resides in accelerometry and the development of more advanced algorithms to account for more finite patterns in the accelerations on two to three axes in various devices.

Secondly consider strategies that best promote physical activity in HD patients, including increasing activity over time. Healthcare system-level is a common barrier to physical activity participation for HD patients (42). For example, dialysis care providers may lack exercise-related knowledge, access to exercise education resources, or time to provide education. Indeed, HD patients are at high risk for cardiovascular disease, and staff support for exercise programme is critical to its success (43). This role can be performed by nurses who 
TABLE 2 | Summary of RCTs for promoting physical activity in HD patients.

\begin{tabular}{|c|c|c|c|}
\hline References & Physical activity measure & Intervention & Findings \\
\hline Sheshadri et al. (26) & $\begin{array}{l}\text { Physical activity was measured as a } \\
\text { daily step count using a pedometer. }\end{array}$ & $\begin{array}{l}\text { Providing pedometers in conjunction } \\
\text { with weekly semi-scripted counseling } \\
\text { sessions, patients were also set a } \\
\text { goal of increasing their step count by } \\
10 \% \text { compared to the previous week. }\end{array}$ & $\begin{array}{l}\text { After } 3 \text { months, patients in the } \\
\text { intervention increased their average } \\
\text { daily steps by } 2,256 \text { ( } 95 \% C l, 978 \text { to } \\
\text { 3,537) more than the controls }(P< \\
\text { 0.001). }\end{array}$ \\
\hline Ortega et al. (27) & $\begin{array}{l}\text { Physical activity measured by Human } \\
\text { Activity Profile. }\end{array}$ & $\begin{array}{l}\text { Progressive exercise intervention at } \\
\text { home or during dialysis over } 16 \\
\text { weeks }\end{array}$ & $\begin{array}{l}\text { Both interventions were equally } \\
\text { effective at increasing physical activity } \\
\text { levels (intradialytic group increases } \\
\text { from } 62.4 \pm 16.6 \text { to } 67.3 \pm 15.6 \text {; } \\
\text { home-based group increases from } \\
51.1 \pm 18.1 \text { to } 54.3 \pm 19.3 \text { ) among } \\
\text { the participants after } 16 \text { weeks with a } \\
\text { significant time effect ( } P=0.012) \text {. }\end{array}$ \\
\hline Cho et al. (28) & $\begin{array}{l}\text { Physical activity measured by a } \\
\text { triaxial accelerometer }\end{array}$ & $\begin{array}{l}\text { A 12-week intradialytic exercise } \\
\text { program ( } 3 \text { times/week). }\end{array}$ & $\begin{array}{l}\text { Patients in the aerobic exercise }(1.02 \\
\pm 0.03 \text { vs. } 1.04 \pm 0.04, P=0.04) \\
\text { and combine exercise }(1.06 \pm 0.05 \\
\text { vs. } 1.09 \pm 0.08, P=0.01) \text { group } \\
\text { increased their metabolic equivalent } \\
\text { at } 12 \text { weeks. }\end{array}$ \\
\hline $\begin{array}{l}\text { Assawasaksakul } \\
\text { et al. (29) }\end{array}$ & $\begin{array}{l}\text { Physical activity measured as daily } \\
\text { step count using a wrist-worn triaxial } \\
\text { accelerometer }\end{array}$ & $\begin{array}{l}\text { A 6-month intradialytic cycle } \\
\text { ergometer for } 60 \mathrm{~min} .\end{array}$ & $\begin{array}{l}\text { The physical activity in the exercise } \\
\text { group was significantly increased } \\
\text { from } 5,613 \text { to } 8,725.1 \text { steps/day in } \\
\text { the sixth month }(P=0.046) \text {. }\end{array}$ \\
\hline Martins et al. (30) & $\begin{array}{l}\text { Physical activity was measured using } \\
\text { a triaxial accelerometer }\end{array}$ & $\begin{array}{l}\text { A 12-weeks moderate-intensity } \\
\text { intradialytic resistance training }\end{array}$ & $\begin{array}{l}\text { After } 12 \text { weeks, patients in the } \\
\text { exercise group increased their } \\
\text { average daily steps by } 1,457.8(95 \% \\
C l,-232.6-3,148.2) \text { than the controls } \\
(P=0.22) \text {. }\end{array}$ \\
\hline Dong et al. (31) & $\begin{array}{l}\text { Physical activity was measured by the } \\
\text { International Physical Activity } \\
\text { Questionnaire. }\end{array}$ & $\begin{array}{l}\text { A 12-week progressive intradialytic } \\
\text { resistance exercise with high or } \\
\text { moderate intensity (3 times/week). }\end{array}$ & $\begin{array}{l}\text { After the } 12 \text {-week intervention, the } \\
\text { differences were statistically } \\
\text { significant in physical activity level } \\
\text { between groups }(P<0.05) \text {. }\end{array}$ \\
\hline Koh et al. (32) & $\begin{array}{l}\text { Physical activity was measured by the } \\
\text { International Physical Activity } \\
\text { Questionnaire. }\end{array}$ & $\begin{array}{l}\text { Intradialytic exercise } 3 \text { times/week for } \\
6 \text { months on a cycle ergometer and } \\
\text { home-based exercise followed a } \\
\text { walking program. }\end{array}$ & $\begin{array}{l}\text { Self-reported physical activity } \\
\text { increased in the intradialytic exercise } \\
\text { group }(P=0.03) \text { but not in the } \\
\text { home-based exercise group ( } P= \\
\text { 0.3). }\end{array}$ \\
\hline Pecoits et al. (33) & $\begin{array}{l}\text { Physical activity measured as daily } \\
\text { step count using an accelerometer }\end{array}$ & $\begin{array}{l}\text { Patients receive high-volume online } \\
\text { hemodiafiltration (HDF) or HD }\end{array}$ & $\begin{array}{l}\text { Patients received HDF was }+538 \\
(95 \% \mathrm{Cl}-330 \text { to } 1,407) \text { steps } / 24 \mathrm{~h} \\
\text { compared with } \mathrm{HD} \text {, but no statistically } \\
\text { significant }(P=0.262) \text {. }\end{array}$ \\
\hline Bohm et al. (34) & $\begin{array}{l}\text { Physical activity was measured using } \\
\text { a biaxial accelerometer }\end{array}$ & $\begin{array}{l}\text { Intradialytic exercise } 3 \text { times/week for } \\
6 \text { months on an ergometer and } \\
\text { home-based walking program using a } \\
\text { pedometer. }\end{array}$ & $\begin{array}{l}\text { There was no statistically significant } \\
\text { change in the amount of physical } \\
\text { activity at any intensity level over time } \\
\text { in either group }(P>0.05) \text {. }\end{array}$ \\
\hline
\end{tabular}

Cl, confidence interval.

have attended specially trained or other staff with a specific interest in exercise. They should understand the benefits of exercise for HD patients, know how to get them started on an exercise programme, and motivate them to continue exercising. Other members of the multidisciplinary team, such as kinesiologists/physiologists, may be a critical factor in the sustainability of physical activity management (44). A review by Bennett et al. (45) reported that the most common factor affecting the sustainability of hemodialysis exercise programmes was the availability of dedicated exercise professionals. Future research should consider the specific value of sports medicine in managing physical activity in hemodialysis patients. And then address the following direction:

1. Potential Disease-Modifying Effects of Increased Physical Activity Levels in HD Patients.

2. Determinants of Physical Function Improvement Among HD Patients Are Helpful to Increase the Level of Physical Activity.

3. The Association of Different Intensities (Light/Moderate/ Vigorous Intensity) Physical Activity With Prognosis (Including Health Status and Mortality) in HD Patients. 
4. Conduct High-Quality RCTs to Assess Whether Increases in Physical Activity Resulting From the Intervention Lead to Improved Health Outcomes.

5. Tailor Physical Activity to the Individual HD Patient, Taking Into Account Exercise Capacity, Illness and/or Disability, Family and Community Environment, and Behavioral and Cultural Factors.

\section{SUMMARY}

Healthcare workers should educate HD patients that physical activity is practical, safe, and feasible for most individuals. HD patients can benefit from even low-intensity physical activity to change health outcomes. During recent years, several clinical guidelines have published to aid physical activity management for $\mathrm{HD}$ patients $(46,47)$. Further, to develop strategies to increase physical activity and improve health outcomes in chronic kidney disease, the Global Renal Exercise Network (GREX) provides a compilation of available resources to serve

\section{REFERENCES}

1. Sun L, Zou LX, Han YC, Huang HM, Tan ZM, Gao M, et al. Forecast of the incidence, prevalence and burden of end-stage renal disease in Nanjing, China to the Year 2025. BMC Nephrol. (2016) 17:60. doi: 10.1186/s12882-016-0269-8

2. Zhang L, Zhao MH, Zuo L, Wang Y, Yu F, Zhang H, et al. China kidney disease network (CK-NET) 2016 annual data report. Kidney Int Suppl. (2020) 10:e97-185. doi: 10.1016/j.kisu.2020.09.001

3. Bi SH, Mu B, Tang Z, Fan M, Wang T, Ahmad S. The history of hemodialysis in China. Hemodial Int. (2020) 24:269-75. doi: 10.1111/hdi.12815

4. Cozzolino M, Mangano M, Stucchi A, Ciceri P, Conte F, Galassi A. Cardiovascular disease in dialysis patients. Nephrol Dial Transplant. (2018) 33:iii28-34. doi: 10.1093/ndt/gfy174

5. Yang C, Yang Z, Wang J, Wang HY, Su Z, Chen R, et al. Estimation of prevalence of kidney disease treated with dialysis in China: a study of insurance claims data. Am J Kidney Dis. (2021) 77:889-97. doi: 10.1053/j.ajkd.2020.11.021

6. Caspersen CJ, Powell KE, Christenson GM. Physical activity, exercise, and physical fitness: definitions and distinctions for health-related research. Public Health Rep. (1985) 100:126-31.

7. World Health Organization. WHO Guidelines On Physical Activity And Sedentary Behaviour. Available online at: https://apps.who.int/iris/ handle $/ 10665 / 336656$ ? search-result=true\&query=physical $\$+\$$ activity\%2C $\$+$ $\$$ sedentary $\$+\$$ behaviour\&scope $=\&$ rpp $=10$ \&sort $\_$by $=$score\&order $=$desc

8. Yamamoto S, Matsuzawa R, Abe Y, Hoshi K, Yoneki K, Harada M, et al. Utility of regular management of physical activity and physical function in hemodialysis patients. Kidney Blood Press Res. (2018) 43:150515. doi: 10.1159/000494016

9. Beddhu S, Wei G, Marcus RL, Chonchol M, Greene T. Light-intensity physical activities and mortality in the United States general population and CKD subpopulation. Clin J Am Soc Nephrol. (2015) 10:114553. doi: 10.2215/CJN.08410814

10. Barcellos FC, Santos IS, Umpierre D, Bohlke M, Hallal PC. Effects of exercise in the whole spectrum of chronic kidney disease: a systematic review. Clin Kidney J. (2015) 8:753-65. doi: 10.1093/ckj/sfv099

11. Johansen KL, Chertow GM, Ng AV, Mulligan K, Carey S, Schoenfeld PY, et al. Physical activity levels in patients on hemodialysis and healthy sedentary controls. Kidney Int. (2000) 57:2564-70. doi: 10.1046/j.1523-1755.2000.00116.x

12. Zelle DM, Klaassen G, van Adrichem E, Bakker SJ, Corpeleijn E, Navis G. Physical inactivity: a risk factor and target for intervention in renal care. Nat Rev Nephrol. (2017) 13:152-68. doi: 10.1038/nrneph.2016.187 patients with all stages of kidney disease (https://grexercise.kch. illinois.edu/). Considering the substantial cost associated with HD treatment and the somewhat theoretical benefit of physical activity, we should focus on keeping HD patients participating in physical activity. Therefore, promoting physical activity should be integrated into lifestyle management for HD patients.

\section{AUTHOR CONTRIBUTIONS}

HW and FZ: conceptualization. WW: writing-original draft preparation. HZ: writing-review and editing. All authors have read and agreed to the published version of the manuscript.

\section{FUNDING}

The study was supported from Longhua Hospital Shanghai University of Traditional Chinese Medicine (Grant Number: Y21026).

13. Hishii S, Miyatake N, Nishi H, Katayama A, Ujike K, Koumoto K, et al. Relationship between sedentary behavior and all-cause mortality in japanese chronic hemodialysis patients: a prospective cohort study. Acta Med Okayama. (2019) 73:419-25. doi: 10.18926/AMO/57372

14. Tamiya H, Tamura Y, Mochi S, Akazawa Y, Mochi Y, Banba N, et al. Extended sedentary time increases the risk of all-cause death and new cardiovascular events in patients with diabetic kidney disease. Circ J. (2020) 84:21907. doi: 10.1253/circj.CJ-20-0407

15. Bennett PN, Kohzuki M, Bohm C, Roshanravan B, Bakker SJL, Viana JL, et al. Global policy barriers and enablers to exercise and physical activity in kidney care. J Ren Nutr. (2021). doi: 10.1053/j.jrn.2021.06.007. [Epub ahead of print].

16. Mok A, Khaw KT, Luben R, Wareham N, Brage S. Physical activity trajectories and mortality: population based cohort study. BMJ. (2019) 365:12323. doi: 10.1136/bmj.12323

17. Tikkanen-Dolenc H, Wadén J, Forsblom C, Harjutsalo V, Thorn LM, Saraheimo M, et al. Physical activity reduces risk of premature mortality in patients with type 1 diabetes with and without kidney disease. Diabetes Care. (2017) 40:1727-32. doi: 10.2337/dc17-0615

18. Matsuzawa R, Roshanravan B, Shimoda T, Mamorita N, Yoneki K. Harada $\mathrm{M}$, et al. Physical activity dose for hemodialysis patients: where to begin? results from a prospective cohort study. J Ren Nutr. (2018) 28:4553. doi: 10.1053/j.jrn.2017.07.004

19. Lopes AA, Lantz B, Morgenstern H, Wang M, Bieber BA, Gillespie BW, et al. Associations of self-reported physical activity types and levels with quality of life, depression symptoms, and mortality in hemodialysis patients: the DOPPS. Clin J Am Soc Nephrol. (2014) 9:1702-12. doi: 10.2215/CJN.123 71213

20. Zhang L, Luo H, Kang G, Wang W, Hu Y. The association between physical activity and mortality among patients undergoing maintenance hemodialysis. Int J Nurs Pract. (2017) 23:e12505. doi: 10.1111/ijn.12505

21. Matsuzawa R, Matsunaga A, Wang G, Kutsuna T, Ishii A, Abe Y, et al. Habitual physical activity measured by accelerometer and survival in maintenance hemodialysis patients. Clin J Am Soc Nephrol. (2012) 7:20106. doi: 10.2215/CJN.03660412

22. O'Hare AM, Tawney K, Bacchetti P, Johansen KL. Decreased survival among sedentary patients undergoing dialysis: results from the dialysis morbidity and mortality study wave 2. Am J Kidney Dis. (2003) 41:44754. doi: 10.1053/ajkd.2003.50055

23. Martins P, Marques EA, Leal DV, Ferreira A, Wilund KR, Viana JL. Association between physical activity and mortality in end-stage kidney disease: a systematic review of observational studies. BMC Nephrol. (2021) 22:227. doi: 10.1186/s12882-021-02407-w 
24. Tentori F, Elder SJ, Thumma J, Pisoni RL, Bommer J, Fissell RB, et al. Physical exercise among participants in the dialysis outcomes and practice patterns study (DOPPS): correlates and associated outcomes. Nephrol Dial Transplant. (2010) 25:3050-62. doi: 10.1093/ndt/gfq138

25. Shimoda T, Matsuzawa R, Yoneki K, Harada M, Watanabe T, Matsumoto M, et al. Changes in physical activity and risk of all-cause mortality in patients on maintence hemodialysis: a retrospective cohort study. BMC Nephrol. (2017) 18:154. doi: 10.1186/s12882-017-0569-7

26. Sheshadri A, Kittiskulnam P, Lazar AA, Johansen KL. A walking intervention to increase weekly steps in dialysis patients: a pilot randomized controlled trial. Am J Kidney Dis. (2020) 75:488-96. doi: 10.1053/j.ajkd.2019.07.026

27. Ortega-Pérez de Villar L, Martínez-Olmos FJ, Pérez-Domínguez FdB, Benavent-Caballer V, Montañez-Aguilera FJ, Mercer T, et al. Comparison of intradialytic versus home-based exercise programs on physical functioning, physical activity level, adherence, and health-related quality of life: pilot study. Sci Rep. (2020) 10:8302. doi: 10.1038/s41598-020-64372-y

28. Cho J-H, Lee J-Y, Lee S, Park H, Choi S-W, Kim JC. Effect of intradialytic exercise on daily physical activity and sleep quality in maintenance hemodialysis patients. Int Urol Nephrol. (2018) 50:74554. doi: 10.1007/s11255-018-1796-y

29. Assawasaksakul N, Sirichana W, Joosri W, Kulaputana O, Eksakulkla S, Ketanun C, et al. Effects of intradialytic cycling exercise on daily physical activity, physical fitness, body composition, and clinical parameters in highvolume online hemodiafiltration patients: a pilot randomized-controlled trial. Int Urol Nephrol. (2021) 53:359-71. doi: 10.1007/s11255-020-02677-7

30. Martins do Valle F, Valle Pinheiro B, Almeida Barros AA, Ferreira Mendonça W, de Oliveira AC, de Oliveira Werneck G, et al. Effects of intradialytic resistance training on physical activity in daily life, muscle strength, physical capacity and quality of life in hemodialysis patients: a randomized clinical trial. Disabil Rehabil. (2020) 42:3638-44. doi: 10.1080/09638288.2019.1606857

31. Dong Z-J, Zhang H-L, Yin L-X. Effects of intradialytic resistance exercise on systemic inflammation in maintenance hemodialysis patients with sarcopenia: a randomized controlled trial. Int Urol Nephrol. (2019) 51:141524. doi: 10.1007/s11255-019-02200-7

32. Koh KP, Fassett RG, Sharman JE, Coombes JS, Williams AD. Effect of intradialytic versus home-based aerobic exercise training on physical function and vascular parameters in hemodialysis patients: a randomized pilot study. Am J Kidney Dis. (2010) 55:88-99. doi: 10.1053/j.ajkd.2009.09.025

33. Pecoits-Filho R, Larkin J, Poli-de-Figueiredo CE, Cuvello-Neto AL, Barra $\mathrm{ABL}$, Gonçalves $\mathrm{PB}$, et al. Effect of hemodiafiltration on measured physical activity: primary results of the HDFIT randomized controlled trial. Nephrol Dial Transplant. (2021) 36:1057-70. doi: 10.1093/ndt/gfaa173

34. Bohm C, Stewart K, Onyskie-Marcus J, Esliger D, Kriellaars D, Rigatto C. Effects of intradialytic cycling compared with pedometry on physical function in chronic outpatient hemodialysis: a prospective randomized trial. Nephrol Dial Transplant. (2014) 29:1947-55. doi: 10.1093/ndt/ gfu248

35. Bakker EA, Zoccali C, Dekker FW, Eijsvogels TMH, Jager KJ. Assessing physical activity and function in patients with chronic kidney disease: a narrative review. Clin Kidney J. (2021) 14:768-79. doi: 10.1093/ckj/ sfaa 156

36. Cobo G, Gallar P, Gama-Axelsson T, Di Gioia C, Qureshi AR, Camacho $\mathrm{R}$, et al. Clinical determinants of reduced physical activity in hemodialysis and peritoneal dialysis patients. J Nephrol. (2015) 28:503-10. doi: 10.1007/s40620-014-0164-y
37. Nawab KA, Storey BC, Staplin N, Walmsley R, Haynes R, Sutherland S, et al. Accelerometer-measured physical activity and functional behaviours among people on dialysis. Clin Kidney J. (2021) 14:950-8. doi: 10.1093/ckj/sfaa045

38. Malhotra R, Kumar U, Virgen P, Magallon B, Garimella PS, Chopra $\mathrm{T}$, et al. Physical activity in hemodialysis patients on nondialysis and dialysis days: prospective observational study. Hemodial Int. (2021) 25:2408. doi: 10.1111/hdi.12913

39. Butler CR, Johansen KL. Beyond exercise: supporting a range of physical activity for people receiving dialysis. Nephrol Dial Transplant. (2021). doi: 10.1093/ndt/gfab288. [Epub ahead of print].

40. Rubenstein JH, Morgenstern H, Kellenberg J, Kalish T, Donovan J, Inadomi $J$, et al. Validation of a new physical activity questionnaire for a sedentary population. Dig Dis Sci. (2011) 56:2678-87. doi: 10.1007/s10620-011-1641-y

41. Evenson KR, Goto MM, Furberg RD. Systematic review of the validity and reliability of consumer-wearable activity trackers. Int J Behav Nutr Phys Act. (2015) 12:159. doi: 10.1186/s12966-015-0314-1

42. Thompson S, Tonelli M, Klarenbach S, Molzahn A. A qualitative study to explore patient and staff perceptions of intradialytic exercise. Clin J Am Soc Nephrol. (2016) 11:1024-33. doi: 10.2215/CJN.11981115

43. Bayliss D. Starting and managing an intradialytic exercise program. Nephrol News Issues. (2006) 20:47-9.

44. Greenwood SA, Koufaki P, Rush R, Macdougall IC, Mercer TH. Exercise counselling practices for patients with chronic kidney disease in the UK: a renal multidisciplinary team perspective. Nephron Clin Pract. (2014) 128:6772. doi: $10.1159 / 000363453$

45. Bennett PN, Breugelmans L, Barnard R, Agius M, Chan D, Fraser D, et al. Sustaining a hemodialysis exercise program: a review. Semin Dial. (2010) 23:62-73. doi: 10.1111/j.1525-139X.2009.00652.x

46. UK Kidney Association. Clinical Practice Guideline: Exercise and Lifestyle in Chronic Kidney Disease. Available online at: https://renal.org/sites/renal. org/files/Exercise\%20and\%20Lifestyle\%20in\%20CKD\%20clinical\%20practice \%20guideline33_v4_FINAL_0.pdf

47. Yamagata K, Hoshino J, Sugiyama H, Hanafusa N, Shibagaki Y, Komatsu Y, et al. Clinical practice guideline for renal rehabilitation: systematic reviews and recommendations of exercise therapies in patients with kidney diseases. Ren Replace Ther. (2019) 5:28. doi: 10.1186/s41100-019-0209-8

Conflict of Interest: The authors declare that the research was conducted in the absence of any commercial or financial relationships that could be construed as a potential conflict of interest.

Publisher's Note: All claims expressed in this article are solely those of the authors and do not necessarily represent those of their affiliated organizations, or those of the publisher, the editors and the reviewers. Any product that may be evaluated in this article, or claim that may be made by its manufacturer, is not guaranteed or endorsed by the publisher.

Copyright (c) 2022 Zhang, Wang, Wang and Zhang. This is an open-access article distributed under the terms of the Creative Commons Attribution License (CC BY). The use, distribution or reproduction in other forums is permitted, provided the original author(s) and the copyright owner(s) are credited and that the original publication in this journal is cited, in accordance with accepted academic practice. No use, distribution or reproduction is permitted which does not comply with these terms. 